\title{
IMPORTANCE OF R\&D EXPENDITURE FOR ECONOMIC GROWTH IN SELECTED CEE COUNTRIES
}

\author{
Irena Szarowská
}

\section{Introduction}

Research and development (R\&D) is of fundamental importance in the creation of knowledge, products and technologies (Solow, 1956; Jones, 1995; Köhler et al., 2012; OECD, 2012; Szarowská, 2016; 2017). Generally, governments have three main instruments for financing $R \& D$ (own $R \& D$, direct funding and indirect funding), each of which has advantages and disadvantages from the perspective of economic theory (David et al., 2000). The financial crisis prompted many governments to introduce tough fiscal consolidation measures and to prioritize other issues over R\&D. However, Hud and Hussinger (2015) note that to prevent firms from reducing their R\&D expenses and to maintain national R\&D capacities, policymakers in many countries reacted immediately to the crisis and increased the public R\&D budget.

Many studies have investigated the determinants of economic growth. The survey of Petrakos and Arvanitidis (2008) identified a number of important determinants of economic dynamism at the global scale. Among others, it was found that the determinants of economic dynamism do not have the same influence in advanced and less advanced countries. Central and Eastern European (CEE) countries form a heterogeneous group of countries and their economic maturity as well as R\&D intensity have been very low after the fall of communism. These countries have faced transition processes from state-run and closed economic systems to developing and competitive open market economies over the last years. One of the key elements of the growth strategy for CEE countries is creating a knowledge-based economy, of course, with governmental support. As attention to this process and to the role of R\&D public support is very limited in published papers, the article focuses on this topic.
The goal of this article is to quantify the effect of R\&D expenditure on economic growth in eight selected CEE countries in the period 1995-2016. The article is organized as follows. The next section presents theoretical background and a brief literature review. The following chapter introduces methodology and data. The empirical part is focused on basic forms of funding $R \& D$ and testing the effect of R\&D expenditure on economic growth. The conclusion summarizes the main findings.

\section{Literature Review and Theoretical Background}

The starting point of many growth concepts is connected with model of Solow (1956), known as the Solow-Swan model which considers long-run economic growth. This model, based on neoclassical production function of the Cobb-Douglas form, is one of the first that considered the impact of technological change on economic growth. The model implies that changes in output (income) per capita or per worker (output and income and population and labour force are synonymous in the model) depend on changes in capital stock (resulting both from investment and capital depreciation), changes in population, and the income share of capital. The used functional relationship can be written as:

$$
Y_{t}=f\left(A_{t}, K_{t}, L_{t}\right)
$$

In equation (1), $Y$ is output, $t$ is the time, $K$ means the capital input, $L$ is the labor input, $A$ denotes the total factor productivity (TFP), which captures the non-inclusive effects, among which technological progress is especially significant factor. The SolowSwan model recognizes the significance of the positive impact of technology on growth, but it is considered exogenous. 
Due to the global macroeconomic disbalances of the 1970's, economists started to focus primarily on business cycle fluctuations and the research turned away from the exogenous models towards endogenous growth models. The development of endogenous growth theory has provided many new visions into the sources of economic growth. Romer (1986) identified R\&D as the major component of economic growth, and he based endogenous growth theory on investment in R\&D capital. Romer considered that R\&D activities generate knowledge that prevents decreasing returns to scale to occur for capital as a factor of production. Romer (1990) subsequently confirmed the results of the model for most of the developer countries by empirical studies. Grosman and Helpman (1991) presented similar approach and argued that R\&D expenditures are vital for economic growth.

In endogenous models, technological progress is generated in R\&D using knowledge accumulation and human capital, compare to exogenous model. An important basis of endogenous growth models is also the assumption about increasing or constant returns to scale of knowledge, due to spill-over effects or so-called "learning by doing." Huňády and Orviská (2014) mentioned that by assuming increasing returns to scale of invention, is possible to get exponential economic growth even with constant R\&D expenditures and when assumed constant returns to scale, it means that the increase in R\&D expenditures should ensure a proportional increase in innovation as well. Therefore, this should lead to the proportional increase of productivity, and, thereby, enable a stable economic growth in the long-term.

Early models of R\&D-based growth postulate that the long-run growth rate of productivity is proportional to the level of research undertaken in the overall economy as e.g., Romer (1990) or Grossman and Helpman (1991) declared. In contrast, Kneller et al. (1999) stated that neoclassical growth models consign the role of fiscal policy to one of determining the level of output rather than the long-run growth rate. The steady-state growth rate is driven by the exogenous factors of population growth and technological progress, while fiscal policy can affect only the transition path to this steadystate.
Afterwards Barro and Sala-i-Martin (1995) modelled technological progress as an expansion of the variety of intermediate goods used by producers. The rate of growth depends on various characteristics of preferences and technology, including the willingness to save, the level of the production function, the cost of R\&D, and the scale of the economy (measured by the quantity of a fixed factor, such as labour or human capital). Barro and Sala-i-Martin's equilibrium growth rate in the model corresponds to the exogenous rate of technological change in the Solow-Swan (1956) model. They noted that if the diffusion of ideas from one country to another is rapid, the model explains why the technology in all countries would improve over time. Therefore, the model can explain why the long-term growth rate of the world's real per capita GDP would be positive.

The first generation of R\&D-based growth models suffered from the scale effect, according to which public policy increases the longrun growth rate with the size of the economy. Jones (1995) criticized a prediction of these models with the scale effect as empirically he did not detect significant positive effect of the number workers increase on economics. That is why, Jones (1995) substituted endogenous models by so-called semi-endogenous models, which are referred to as of semi-endogenous growth as they contend that the growth rate of productivity is ultimately driven by the (exogenous) population growth rate.

Minniti and Venturini (2017) reported that another line of research known as fullyendogenous growth theory builds upon the insight that aggregate R\&D effort becomes less effective because it spreads among a greater number of product lines. Productivity growth would depend on the R\&D intensity at the firm level, explaining why growth can be stationary despite the increasing resources invested in R\&D. Accordingly, any policy that affects R\&D intensity has also an impact on the steady-state growth rate.

A second generation of R\&D-based growth models (called non-scale growth models) is not spurred by the scale effect. These models imply a strong ineffectiveness proposition and state that public policy is powerless to increase or affect the long-run growth rate. Perez-Sebastian (2007) noted that even policy in Jones-type non-scale models (1995) has no long-run growth effects, and level effects can be substantial. 
Newly, Afonso (2016) designed a theoretical R\&D endogenous growth model for explaining the co-movement of R\&D intensity, economic growth and firm-size growth in 10 innovative countries, exploring short-medium-run and long-term growth effects. He mentioned that $R \& D$ is more labor-intensive through time as complexity increases, and that when economy is not initially in a steady state, it can take a saddle path towards the unique and locally seated path stable internal steady state.

Many economists have examined factors influencing economic growth, and theoretical approaches have been accompanied by a growing number of empirical studies. Consistent with the purpose of this study, the empirical literature review is primarily focused on the effect of R\&D. Guellec and de la Potterie (2004) introduced factors important for growth, namely, absorptive capability, origin of funding, socioeconomic objectives of government support, and type of public institutions that perform R\&D. Garland and Allen (1995) analyzed the relative importance of public and private R\&D in the economic growth of different countries. They confirmed that private R\&D has a greater impact on growth than public R\&D, which is to a large degree devoted to basic research. Bilbao-Osorio and Rodriguez-Pose (2004) presented results that indicate that R\&D investment, as a whole, and higher education R\&D investment in peripheral regions of the $E U$, in particular, are positively associated with innovations. The existence and strength of these associations are depending upon region-specific socio-economic characteristics that affect the capacity of each region to transform R\&D investment into innovation and economic growth. Similarly, Berliant and Fujita (2011) stated that long-run economic growth is positively related to the effectiveness of pairwise R\&D worker interaction and to the effectiveness of public knowledge transmission.

Petrakos and Arvanitidis (2008) identified determinants consistent with the relevant mainstream literature (human capital, innovation, openness, FDI and infrastructure), but also with its most recent developments, highlighting the increasing importance of political and institutional factors.

As empirical literature offers support for the varied impacts of R\&D on economic growth positive, negative and zero, Köhler et al. (2012) summarized the results of 18 published papers and noted that despite a growing number of studies on the effect of R\&D expenditure and tax incentives, knowledge about the effectiveness of R\&D expenditure and how a scheme should be designed to maximize its impact, remains limited. Likewise, Becker (2015) offered the most systematic review and critical discussion focused on R\&D literature, with attention paid to mutual comparison between findings of published studies, but irreversible conclusions is not possible to define.

There is a group of studies presenting differences in relationship between R\&D expenditure and economic growth based on territory specification, economic maturity or duration of effect. Sylwester (2001), for instance, examined 20 OECD countries and used the aggregate data employing a multivariate regression. He found a statistically significant relationship between $R \& D$ expenditure and economic growth when only G-7 countries of a sub-sample are considered. The results for the full sample are found irrelevant. Köhler et al. (2012) also confirmed the hypothesis that technological change stimulates economic growth. The less advanced EU regions in particular, whose public expenditure in R\&D is higher, report higher GDP growth rates. Inekwe (2015) explored the role of R\&D expenditure on the economic growth of 66 developing economies between 2000 and 2009. The effect of R\&D expenditure on growth is positive for upper middle-income economies and insignificant in lower-income economies. R\&D expenditure has different short- and long-run effects on growth. Alike, Gumus and Celikay (2015) provided an empirical analysis of the relationship between R\&D expenditures and economic growth, and determined whether this relationship differs with respect to the degree of development utilising 52 countries from 1996 to 2010 and applying a dynamic panel data model. In this regard, R\&D expenditure has a positive and significant effect on economic growth for all countries in the long-run. On the other hand, the effect is weak in the short run but strong in the long run for developing countries. Sokolov-Mladenovic et al. (2016) investigated the influence of $R \& D$ expenditure on economic growth in the EU28 during the period of 2002-2012. Results of a multiple regression model showed that, ceteris paribus, an increase in R\&D expenditure as a percentage of GDP by $1 \%$ would cause an 
increase of real GDP growth rate by $2.2 \%$. This model takes into consideration actual financial crises and emphasizes the negative influence of fertility rate in the EU28 on economic growth.

One of the fundamental papers devoted to the CEE region was published by Chvojka and Zeman (2000). They reviewed the economic potential of the ten analyzed CEE countries at the beginning of the transformation process and analyzed the differences in subsequent economic growth, restructuring trends, the competitive ability, and proper policy approach necessary to stimulate the transformation process towards a market economy. Anyway, the empirical literature focused on determinants of growth in CEE economies is often concentrate on the role of European integration and the EU enlargements. Simionescu et al. (2017) noted that a long-run economic growth was registered in the CEE region in 1995-2013 mainly because of the fast rhythm of growth after the EU accession. Simionescu et al. (2017) also provided an empirical analysis of factors that might determine a stable economic growth in Visegrad countries and Romania for the period of 2003-2016. The main results indicated that expenditure on education generated economic growth only in the Czech Republic, while the expenditure on R\&D had positive effects in Romania, Hungary and the Czech Republic. As well Baran (2013) researched main determinants of growth in Visegrad countries (during 1995-2010) by applying two methods: Solow growth approach and a non-parametric approach that enables the further decomposition of changes in TFP into changes in efficiency of production and technological changes. The growth approach points out that in the Czech Republic and Slovak Republic TFP and capital accumulation seem to have relatively equal contribution to growth, in Hungary capital accumulation was the main source of growth, while in Poland TFP accounted for $70 \%$ of total growth. The further decomposition reveals that the productivity growth was driven mainly by efficiency improvements (technological catchup) and by human capital accumulation, rather than technological change or physical capital accumulation. Likewise Silaghi et al. (2014) empirically estimated the role of private and public R\&D in the growth of CEE countries during 1998-2008, and public R\&D is found to be statistically insignificant. Then Silaghi and Alexa (2015) examined 10 CEE countries over the period 1993-2008 and revealed, on average, capital per worker accumulation is the main driver of growth in CEE, followed by the contribution of total factor productivity (TFP). Moreover, the TFP is the main factor of growth in the Czech Republic, Slovakia, Hungary, Lithuania and Romania in sub-period 19972004.

Bilas et al. (2016) wrote that the issues of economic growth are constantly re-evaluated, especially after consequences of the economic and financial crisis of 2008-2009. They empirically validated the Granger causality between R\&D expenditure and gross domestic product growth for EU countries in the period 2003-2013. In a next step, they used dynamic panel data and determined that expenditure on R\&D on average depends on expenditure on R\&D in the previous year, with the coefficient 0.77 , and on annual GDP per capita growth rate, with the coefficient -0.0073 . Pilinkiene (2016) stated that CEE countries are characterized by high indicators of trade openness. Her analysis based on Granger-causality test and VAR model revealed that the high-degree trade openness provides the conditions relevant to economic growth in CEE countries.

\section{Methodology and Data}

The aim of the article is to quantify the effect of R\&D expenditure on economic growth. Empirical evidence is based on unbalanced annual panel data of the selected CEE countries in the period 1995-2016 (the longest available time series). The sample selection is limited by the availability of data. That is why the empirical evidence identifying the direct impact of R\&D expenditure and other control variables on GDP growth is performed for $8 \mathrm{EU}$ countries, namely, Bulgaria (BG), the Czech Republic (CZ), Hungary (HU), Latvia (LV), Poland (PO), Romania (RO), Slovak Republic (SK) and Slovenia (SI). From a methodological perspective, the research applies Dumitrescu Hurlin (DH) causality and a dynamic panel regression methodology, based on Solow's growth model which is adapted to the framework of this study. The software E-Views (9) is used for estimations.

Dumitrescu and Hurlin (2012) developed this advanced form of Granger causality analysis. The main benefit of the $\mathrm{DH}$ panel analysis is its possible application for analyzing unbalanced panel data and cross-sectional 
dependency between countries. The essential requirement of the method is that variables used in the analysis should be stationary on their level values. The details of this test are explained on the following equation (2).

$$
\begin{aligned}
& y_{i t}=\alpha_{i}+\sum_{k=1}^{K} \gamma_{i}^{(k)} y_{i t-k}+ \\
& +\sum_{k=1}^{K} \beta_{i}^{(k)} y_{i t-k}+\varepsilon_{i t} \\
& i=1,2, \ldots, N ; t=1,2, \ldots, T
\end{aligned}
$$

In the equation (2), $x$ and $y$ are two stationary variables observed for $N$ individuals in $T$ periods.

$\beta_{i}=\left(\beta_{i}(1), \ldots, \beta_{i} K\right)^{\prime}$ and the individual effects $\alpha_{i}$ are assumed to be fixed in the time dimension. It is assumed that lag orders of $K$ are identical for all cross-section units of the panel, and $\varepsilon$ means the error term. The autoregressive parameters $\gamma_{i}^{(k)}$ and the regression coefficients $\beta_{i}^{(k)}$ vary across groups. The test statistic depends on the individual Wald statistics of Granger non-causality averaged across the cross-section units.

The panel regression methodology is chosen as it has a very important option of including individual effects (i.e., the existence of heterogeneity across cross-sectional units) compared to cross-sectional analyses. This option makes the presented evidence more credible, given the relatively small number of countries and short time series as it is in this dataset due to annual frequency of data. The below models include a lag of one period and fixed effects as are usual in this type of study (Perez-Sebastian, 2007; Silaghi et al., 2014). A general panel model with fixed effects can be formally written as:

$$
\begin{aligned}
& y_{i, t}=\alpha_{i}^{*}+\beta^{\prime} X_{i t}+\varepsilon_{i t} \\
& i=1,2, \ldots, N ; t=1,2, \ldots, T
\end{aligned}
$$

where $y_{i t}$ depends on a set of $K$ explanatory variables $x_{i t}$ and the constants are specific to the $i$-th unit (country) at time $t$, at the same time but are constant. $\beta$ ' is the vector dimension $1 \times K$ constants and $\alpha_{i}^{*}$ is a constant representing the effects of those variables, which are characteristic of the $i$-th observation. $\varepsilon_{i t}$ error component represents non-significant effects of variables inherent in the $i$-team observations and a given time interval. Furthermore, the error is assumed not to correlate with the vector $x_{i t}$ for all $i$ and $t$, and it has an independent identical distribution with zero mean and constant dispersion (Dougherty, 2007). Both fixed effects and random effects regressions were performed before analysis. A Durbin-Wu-Hausman test indicated significant differences in the coefficients, so the model with fixed effects is used in the paper. The suitability of the fixed effects model can be assessed using the F-test, too, which is strongly justified in this case. Furthermore, the Wooldridge test for autocorrelation in panel data shows that at the $5 \%$ significance level, the null hypothesis of no auto-relation cannot be rejected (Verbeek, 2012).

Many studies note that using nonstationary macroeconomic variables in time series analysis causes superiority problems in regression. Thus, a unit root test should precede any empirical study employing such variables. Recent literature suggests that panel-based unit root tests have higher power than unit root tests based on individual time series. Panel unit root tests are similar, but not identical, to unit root tests carried out on a single series (Arellano \& Bond, 1991). Panel unit root tests ((Levin, Lin, \& Chu, 2002; Breitung, 2000; Im et al., 2003); Fisher-type tests using ADF and Fisher PP tests) that have been used confirm the stationarity of all-time series on the first difference (except GDP, which is stationary on level data). Therefore, the first differences of variables were estimated and are used in the model.

To quantify the effect of R\&D expenditure on economic growth in the long term, there are estimated econometric models. In our case, the dependent variable used in the models is economic growth approximated by GDP growth and the independent variables under investigation include determinants consistent with the relevant mainstream literature, specifically traditional growth variables, R\&D expenditure and control variables. The model specification is created as follows.

A standard Solow growth model is specified in equation (1). If it is assumed that the functional form of equation (1) is Cobb-Douglas form, then:

$$
Y_{t}=A_{t} K_{t}^{\alpha} L_{t}^{\beta}
$$

where $\alpha$ and $\beta$ are shares of capital and labour, respectively.

The majority of the literature on economic growth indicates that there is a large number of 
variables that can affect the $\operatorname{TFP}\left(A_{t}\right)$ in equation (4). Let

$$
\begin{aligned}
& A_{t}=f\left(G E R D_{t}, I_{N}, \operatorname{HRST}_{t}, \text { OPEN }_{t}\right)= \\
& =G E R D_{t}^{\delta 1} I N V_{t}^{\delta 2} \operatorname{HRST}_{t}^{\delta 3} \operatorname{OPEN}_{t}^{\delta 4}
\end{aligned}
$$

Then by substituting equation (5) into equation (4), it is possible to obtain the following extended form

$$
Y_{t}=K_{t}^{\alpha} L_{t}^{\beta} G E R D_{t}^{\delta 1} I N V_{t}^{\delta 2} \operatorname{HRST}_{t}^{\delta 3} \operatorname{OPEN}_{t}^{\delta 4}
$$

where $G E R D_{t}$ is gross domestic expenditure on R\&D ratio, $I N V_{t}$ means the investment ratio, $H R S T_{t}$ represents labour force and OPEN expresses country openness.

The standard procedure for estimating equation (6) is by first log-linearizing it. By processing the natural logarithm of equation (6) and taking into account the equation (3) for a general panel model with fixed effects, the basic panel model is defined in (7) and variable specification is explained below:

$$
\begin{aligned}
& \ln G D P_{i t}=\delta_{0}+\delta_{1} d G E R D_{i t}+\delta_{2} d I N V_{i t}+ \\
& +\delta_{3} d H R S T_{i t}+\delta_{4} d O P E N_{i t}+\varepsilon_{i t}
\end{aligned}
$$

where $\delta_{1}$ to $\delta_{4}$ contain the coefficients assigned to the independent variables, and $\delta_{0}$ is a constant, the subscript $t$ indexes the year and $i$ country. GDP means GDP growth expressed by the amount of GDP per capita in purchasing power standards; the series for GDP are transformed into natural logarithms. GERD means gross domestic expenditure on R\&D as a percentage of GDP, INV expresses the investment ratio to GDP, HRST as a share of the active population classified as HRST (i.e., having successfully completed an education at the tertiary level or being employed in science and technology) as a percentage of total active population aged $15-74$, and $\varepsilon$ is the error term. OPEN implies the openness ratio as the sum of imports and exports divided by GDP. All the data were collected from the Eurostat database on economy and finance.

A dynamic panel regression is defined in (8) and reflects development of GDP better as GDP growth changes are influenced by earlier GDP growth.

$$
\begin{aligned}
& \operatorname{InGDP}_{i t}=\delta_{0}+\delta_{1} \operatorname{InGDP}_{i t-1}+\delta_{2} d G E R D_{i t}+ \\
& +\delta_{3} d I N V_{i t}+\delta_{4} d H R S T_{i t}+\delta_{5} d O P E N_{i t}+\varepsilon_{i t}
\end{aligned}
$$

Finally, the dummy variable is added to the specification of a model to focus on crisis impact. Dummy is equal to 0 in pre-crisis and post-crisis years, and equal to 1 in the period 2008-2011. The final equation is defined in (9).

$$
\begin{aligned}
& \ln G D P_{i t}=\delta_{0}+\delta_{1} \ln G D P_{i t-1}+ \\
& +\delta_{2} d G E R D_{i t}+\delta_{3} d I N V_{i t}+\delta_{4} d H R S T_{i t}+(9) \\
& +\delta_{5} d O P E N_{i t}+d u m m y_{i t}+\varepsilon_{i t}
\end{aligned}
$$

R\&D expenditure is expressed not only as total GERD, but it is also divided in its main components by performing sectors: business R\&D (BUSINESS), government (GOV) and higher education (EDU) R\&D expenditure. In this way, it is possible to assess which types of activities have an effect on economic growth.

\section{Results and Discussion}

This section is focused on R\&D financial support and also presents results of testing the effect of R\&D expenditure on economic growth in the country sample.

\subsection{Financial Support of R\&D in CEE Countries}

CEE countries are in a long process of transforming into knowledge-based economies. After political changes, countries in the CEE region began their transformation from different levels, currently they differ in terms of their size, level of economic development, government priorities as well as living standards. Kravtsova and Radosevic (2012) point out that growth in CEE countries before 2008 was driven by domestic consumption, growth in nontradeable sectors and, to a large extent, by total factor productivity or what is conventionally defined as "technological progress." However, evidence suggests that productivity was not driven by technological capabilities, but rather by production capability. Current policies are closely focused on R\&D-based growth and do not address the key drivers of technology accumulation and productivity growth. Disadvantage can be seen in a fact that CEE countries over-prioritize attracting foreign direct investment and do not place enough emphasis on the quality of subsidiary developments.

R\&D is known as essential for the competitiveness of knowledge-based economies, and support of R\&D and innovation is also a political measure. In line with the Lisbon 


\section{Fig. 1: R\&D expenditure in \% GDP}

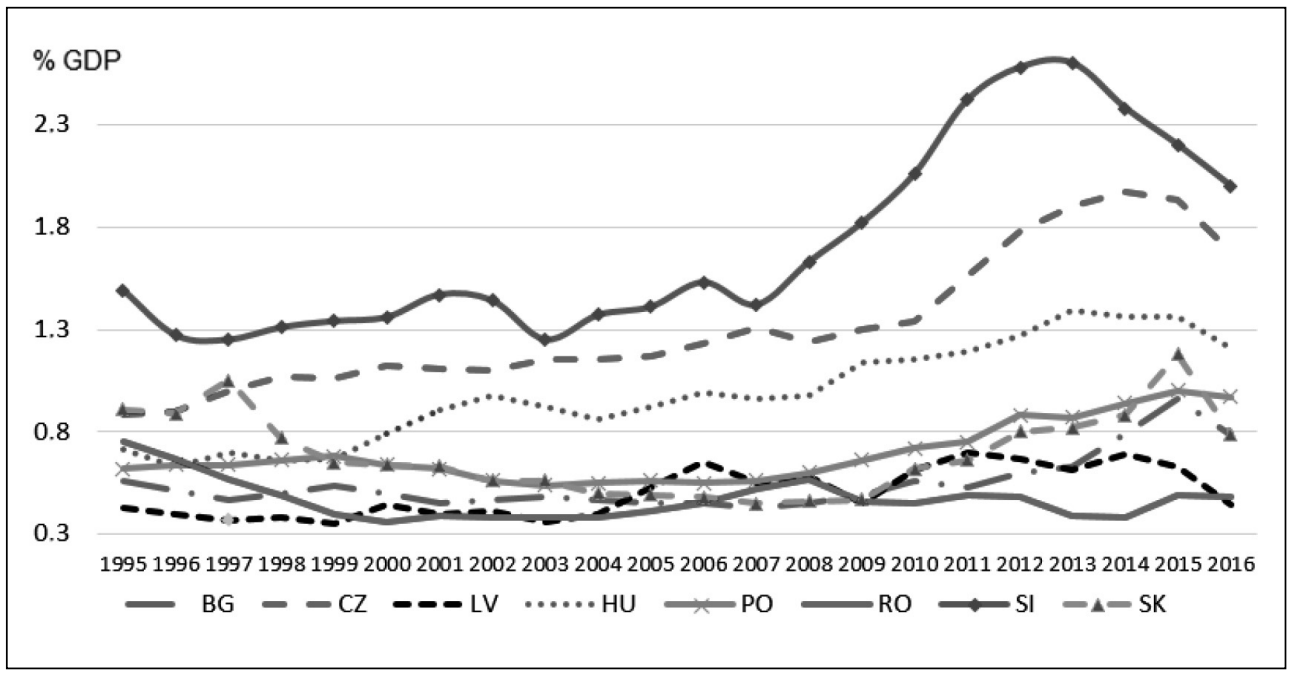

Source: based on data from Eurostat database

strategy and Europe 2020 targets (European Commission, 2014), investment in European R\&D should be raised to $3 \%$ of GDP (increasing combined public and private investment in R\&D) by 2020 , but this target has not yet been reached. Gross domestic expenditure on R\&D (GERD) is the total intramural expenditure on $R \& D$ performed on the national territory during a given period. GERD includes R\&D performed within a country and funded from abroad but excludes payments for R\&D performed abroad. GERD is usually reported for sectors of performance: business enterprise, higher education, government and private not-forprofit institutions serving households.

The European Commission's Innovation Union Scoreboard 2014 shows that among countries taking part in their survey, only Estonia is ranked in the group of so-called innovation followers (those whose innovation performance is close to or above the EU average). Croatia, the Czech Republic, Hungary, Lithuania, Poland and Slovak Republic are among the moderate innovators with performance below the EU average, while Bulgaria, Latvia and Romania are rated as modest innovators (with innovation performance well below the EU average).

Fig. 1 reports development of R\&D expenditure (GERD) in a sample of countries.
The EU-28's average R\&D expenditure was $2.03 \%$ GDP (Eurostat database and OECD, 2017). The importance of the source of funding has been recognized in one of the Barcelona targets of the Lisbon agenda, where it is said that the appropriate split for R\&D is $1 / 3$ financed by public funds and $2 / 3$ by private (European Commission, 2013). As OECD (2015) reports, the business sector accounts for the largest share of R\&D performed in most economies and more than $60 \%$ of expenditure on R\&D (GERD). This share has remained fairly stable over the past decade. Higher education R\&D accounts for almost $20 \%$ of total GERD. The government sector plays a relatively minor role as a performer of R\&D, but it is a major funder of R\&D performed in the higher education and business sectors. R\&D is typically concentrated in a limited number of firms, of which large ones are typically over-represented. In some countries, however, small and mediumsized firms (SMEs) account for a significant share of total business R\&D. SMEs receive a relatively large share of government funding in several countries including Estonia and Slovak Republic. The distribution of business R\&D by economic activity reveals a pattern of specialization influenced by a country's economic structure. In most countries, a limited 


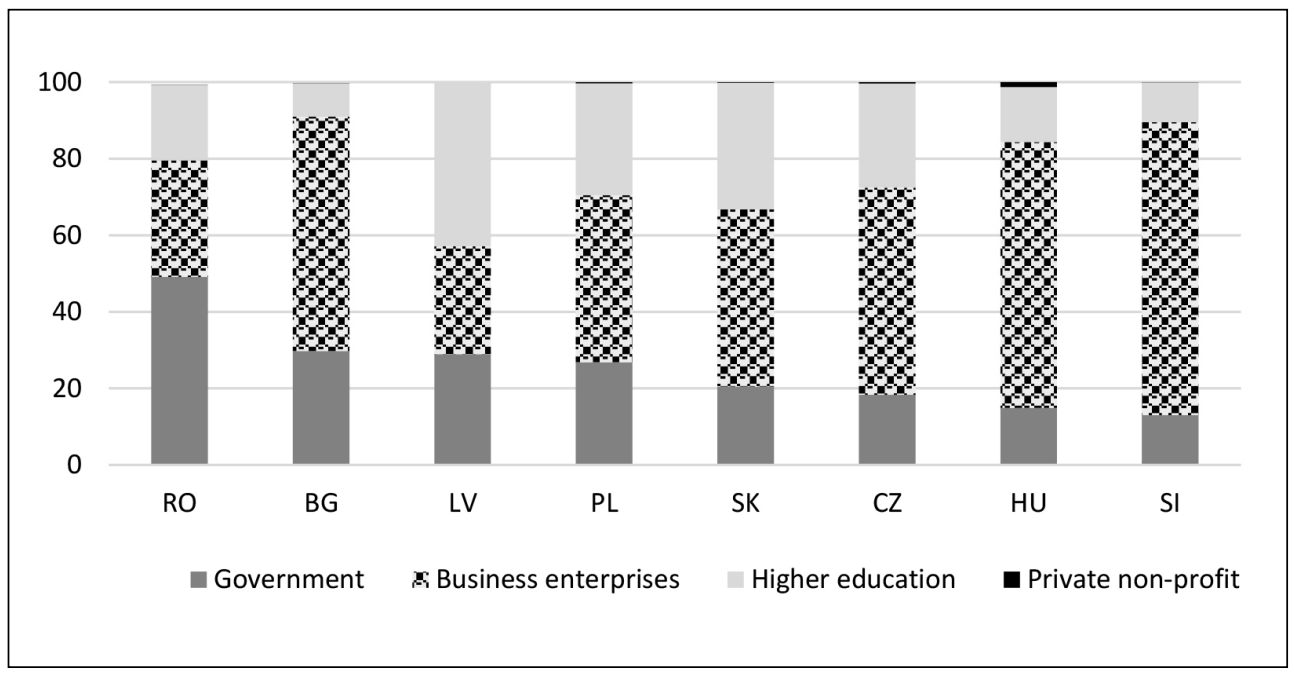

Source: author's compilation based on data from Eurostat

number of activities account for a large share of total business R\&D.

Fig. 2 shows total R\&D expenditure (GERD) divided into performing sectors in 2016 (the latest available time series) in analyzed countries. Slovenia, Hungary and Bulgaria have met the recommended required limits, as private R\&D expenditure is $75.5 \%$ in Slovenia and more than $73 \%$ in Hungary and Bulgaria. A different structure of R\&D expenditure is reported in Latvia with only $25 \%$ of business enterprise R\&D expenditure. This country supports primarily higher education and government R\&D expenditure.

Although it is not a key aspect of the research, it should be taken into account difference between basic and applied research, which are seen as activities with different function, performed by different subjects and founded from different sources. While basic research is completely theoretical, applied research has a practical approach. The main goal of the basic research is to develop new scientific knowledge. On the other hand, applied research focuses on solving concrete problems from business, society, political or economics. Due to „purity“ of basic research, government tends to be the primary funder of basic research (mainly at universities), owing to the need for sustained investment over the long term as report OECD (2017). After 2008, European Commission has maintained its commitment to basic research, which is essential for competitiveness of a country. On average in the EU, $54 \%$ of the government's budget appropriation for R\&D went to basic research in 2015. However, there are wide variations from one country to another in accordance with their preferences, economic maturity and tradition. But for a long run economic and social development is necessary existence of a mix of basic and applied research with their mutual cooperation and support.

In any case, limited financial resources and the pressure to balance expenditure on innovation against expenditure on other policies force governments to look for new instruments. That is why direct R\&D funding is accompanied with indirect public funding. This is mostly realized as tax incentives and is usually more neutral than direct support in terms of industry, region and firm characteristics, although this does not exclude some differentiation, most often by firm size. While direct support is more targeted towards basic and long-term research, R\&D tax schemes are more likely to encourage short-term applied research. Since 2008, indirect support has recently become 
more important to encourage investment in R\&D, and at least one form of stimulus R\&D currently exists in 26 EU countries. Within the EU, only Germany and Estonia currently do not have a tax policy aimed directly at stimulating innovation.

Tab. 1 summarizes available $R \& D$ incentives applied in 2014 in the country sample. Each country chooses and applies specific forms of tax measures in line with a complex strategy for R\&D, R\&D policy, economic development, objectives in terms of competitiveness and historical experience and tradition. Based on collected data, it is found that cash grants and tax deductions are the tools most often used for support and funding of R\&D in the selected CEE countries.

There is a problem with empirical investigating effects of taxes and tax incentives on growth as they are difficult to isolate and quantify. But it is possible to find some studies focused on the topic. For instance, Hall and Van Reenen (2000) studied the econometric evidence on the effectiveness of fiscal incentives for R\&D and concluded that a dollar in tax credit for R\&D stimulates a dollar of additional R\&D. Gemmell et al. (2015) reported tax effects on
GDP growth changes in factor productivity, and importance of transmission channels of taxation on GDP growth.

\subsection{Results of Dumitrescu Hurlin Causality}

Panel DH causality tests are applied for examining the relations between GDP growth and GERD as well as other selected variables in the short term; the results are given in Tab. 2 . Although the aim of this analysis is to detect whether $X$ is the cause of $Y$ or not, it is important to mention that the statement for the example "INV homogeneously causes GDP" does not imply that GDP is the effect or the result of INV. DH causality, as well as Granger causality, measures precedence and information content but does not by itself indicate causality in the more common use of the term. The null hypothesis should be rejected if probability is less than 0.05 (usual level of statistical significance).

Tab. 2 summarises results for a lag of one and two years. Bold values indicate a hypothesis that should be rejected. One can find three examples of $D H$ causality from $R \& D$

\section{Tab. 1: $\quad$ Available R\&D tax incentives (2015)}

\begin{tabular}{|c|c|c|c|c|c|c|c|c|}
\hline & Bulgaria & $\begin{array}{c}\text { Czech } \\
\text { Republic }\end{array}$ & Hungary & Latvia & Poland & Romania & $\begin{array}{c}\text { Slovak } \\
\text { Republic }\end{array}$ & Slovenia \\
\hline $\begin{array}{l}\text { Accelerated } \\
\text { depreciation on R\&D } \\
\text { assets }\end{array}$ & yes & & & yes & & yes & & \\
\hline Cash grants & & yes & yes & & yes & & yes & yes \\
\hline Financial support & & & & & & & & yes \\
\hline $\begin{array}{l}\text { Infrastructure/land } \\
\text { preferential price }\end{array}$ & & yes & & & & & yes & yes \\
\hline Loans & & & & & & & & yes \\
\hline $\begin{array}{l}\text { Patent-related } \\
\text { incentives }\end{array}$ & & & yes & & & & yes & \\
\hline Reduced tax rate & & & yes & & & & & \\
\hline Reduced SSC & & & yes & & & & & \\
\hline Tax deduction & yes & yes & yes & yes & yes & yes & & yes \\
\hline Tax credits & & & yes & & & & yes & \\
\hline Tax exemptions & & & & & yes & & & \\
\hline Tax holiday & & yes & & & & & yes & \\
\hline
\end{tabular}




\begin{tabular}{l|c|c}
\multirow{2}{*}{ Null Hypothesis: } & Lag: $\mathbf{1}$ year & Lag: $\mathbf{2}$ years \\
\cline { 2 - 3 } & Probability values & Probability values \\
\hline GERD does not homogenously cause GDP & 0.904 & 0.458 \\
GDP does not homogenously cause GERD & $\mathbf{0 . 0 4 9}$ & $\mathbf{2 . E - 0 5}$ \\
\hline HRST does not homogenously cause GDP & $\mathbf{0 . 0 4 5}$ & 0.041 \\
GDP does not homogenously cause HRST & 0.053 & 0.087 \\
\hline INV does not homogenously cause GDP & 0.365 & 0.627 \\
GDP does not homogenously cause INV & 0.850 & 0.973 \\
\hline OPEN does not homogenously cause GDP & $\mathbf{0 . 0 4 6}$ & $\mathbf{0 . 0 2 7}$ \\
GDP does not homogenously cause OPEN & 0.850 & 0.973 \\
\hline GOV does not homogenously cause GDP & 0.152 & 0.910 \\
GDP does not homogenously cause GOV & $\mathbf{0 . 0 0 4}$ & 0.094 \\
\hline BUSINESS does not homogenously cause GDP & 0.158 & $\mathbf{0 . 0 0 2}$ \\
GDP does not homogenously cause BUSINESS & $\mathbf{0 . 0 0 1}$ & $\mathbf{9 . E}-11$ \\
\hline EDU does not homogenously cause GDP & $\mathbf{0 . 0 3 7}$ & 0.989 \\
GDP does not homogenously cause EDU & 0.513 & 0.958 \\
\hline
\end{tabular}

and other variables (country openness OPEN, higher education EDU and HRST) to GDP for the 1 year lag. This causality is expected and consistent with the theoretical assumption. Opposite DH causality (from GDP) is confirmed for GERD and BUSINESS expenditure. Similar results are registered for the lag of 2 years. Newly, there is reported bi-causality between GDP and business R\&D expenditure. It can be connected with support for applied research aimed at providing solutions to specific practical problems and developing innovative technology which may be beneficial and contributing to GDP growth. The results also mean that CEE countries which have higher openness ratio, $E D U$ expenditure and HRST arrange the environment conducive to economic growth. A deeper analysis focused on the direct effect of variables follows.

\subsection{Testing Effect of R\&D Expenditure on Economic Growth}

To quantify and test whether R\&D expenditure affects economic growth, there are estimated econometric models. Variables in models are chosen in line with the above empirical studies. Information criteria identified 1 year as the optimal time lag. Tab. 3 presents the most appropriate specifications of models resulting from panel regressions.

In Model 1, series for R\&D expenditure are expressed as GERD, and the basic dynamic panel model is defined in equation (8). Model 2 contains the dummy variable, which is added to the model with the aim to include a crisis impact. The dummy is equal to 0 in the years 1995-2007 as well as in 2012-2016, and equal to 1 in the period 2008-2011. Its presence increases the statistical quality of the models. Next, GERD is divided and substituted by its main components (BUSINESS, GOV and EDU). In this way, it is possible to analyse the R\&D impact of each performing sector. Model 3 is defined in equation (10).

$$
\begin{aligned}
& \operatorname{lnGDP} P_{i t}=\delta_{0}+\delta_{1} \operatorname{lnGDP} P_{i t-1}+ \\
& +\delta_{2} d G O V_{i t}+\delta_{3} d B U S I N E S S_{i t}+ \\
& +\delta_{4} d E D U_{i t}+\delta_{5} d I N V_{i t}+\delta_{6} d H R S T_{i t}+ \\
& +\delta_{7} d O P E N_{i t}+\varepsilon_{i t}
\end{aligned}
$$




\section{Ekonomie}

\section{Tab. 3: Panel regression estimations}

\begin{tabular}{|c|c|c|c|c|c|c|c|c|}
\hline & \multicolumn{2}{|c|}{ Model 1} & \multicolumn{2}{|c|}{ Model 2} & \multicolumn{2}{|c|}{ Model 3} & \multicolumn{2}{|c|}{ Model 4} \\
\hline \multirow[t]{2}{*}{$\begin{array}{c}\text { Dependent } \\
\text { Variable }\end{array}$} & \multicolumn{2}{|c|}{ InGDP } & \multicolumn{2}{|c|}{ InGDP } & \multicolumn{2}{|c|}{ InGDP } & \multicolumn{2}{|c|}{ InGDP } \\
\hline & Coefficient & Std. Error & Coefficient & Std. Error & Coefficient & Std. Error & Coefficient & Std. Error \\
\hline Constant & $0.443^{*}$ & 0.153 & $0.324^{* *}$ & 0.229 & $0.345^{*}$ & 0.212 & 0.333 & 0.230 \\
\hline $\operatorname{lnGDP}_{-1}$ & $0.774^{*}$ & 0.021 & $0.984^{*}$ & 0.020 & $0.974^{*}$ & 0.019 & $0.985^{\star}$ & 0.021 \\
\hline dGERD & 0.032 & 0.044 & 0.055 & 0.047 & & & & \\
\hline dGOV & & & & & $0.035^{\star *}$ & 0.110 & $0.035^{\star *}$ & 0.107 \\
\hline dBUSINESS & & & & & $0.020^{*}$ & 0.046 & $0.020^{*}$ & 0.041 \\
\hline dEDU & & & & & 0.011 & 0.102 & 0.016 & 0.110 \\
\hline dINV & 0.007 & 0.001 & 0.005 & 0.001 & 0.006 & 0.005 & 0.006 & 0.001 \\
\hline dHRST & $0.008^{* *}$ & 0.003 & $0.005^{\star *}$ & 0.003 & $0.008^{* *}$ & 0.003 & $0.006^{* *}$ & 0.003 \\
\hline dOPEN & $0.033^{* *}$ & 0.033 & $0.031^{* *}$ & 0.021 & $0.027^{*}$ & 0.048 & $0.026^{*}$ & 0.045 \\
\hline dummy & & & $-0.049^{*}$ & 0.010 & & & $-0.030^{*}$ & 0.007 \\
\hline $\begin{array}{l}\text { Total } \\
\text { observations }\end{array}$ & \multicolumn{2}{|c|}{164} & \multicolumn{2}{|c|}{164} & \multicolumn{2}{|c|}{164} & \multicolumn{2}{|c|}{164} \\
\hline $\mathrm{R}^{2}$ - Adjusted & \multicolumn{2}{|c|}{0.858} & \multicolumn{2}{|c|}{0.888} & \multicolumn{2}{|c|}{0.896} & \multicolumn{2}{|c|}{0.909} \\
\hline $\mathrm{R}^{2}$ & \multicolumn{2}{|c|}{0.858} & \multicolumn{2}{|c|}{0.898} & \multicolumn{2}{|c|}{0.898} & \multicolumn{2}{|c|}{0.909} \\
\hline $\begin{array}{l}\text { S.E. of } \\
\text { regression }\end{array}$ & \multicolumn{2}{|c|}{0.042} & \multicolumn{2}{|c|}{0.041} & \multicolumn{2}{|c|}{0.042} & \multicolumn{2}{|c|}{0.142} \\
\hline $\begin{array}{l}\text { Prob } \\
\text { (F-statistic) }\end{array}$ & \multicolumn{2}{|c|}{0} & \multicolumn{2}{|c|}{0} & \multicolumn{2}{|c|}{0} & \multicolumn{2}{|c|}{0} \\
\hline $\begin{array}{l}\text { Durbin } \\
\text {-Watson } \\
\text { statistics }\end{array}$ & \multicolumn{2}{|c|}{1.864} & \multicolumn{2}{|c|}{1.932} & \multicolumn{2}{|c|}{1.878} & \multicolumn{2}{|c|}{1.916} \\
\hline
\end{tabular}

Source: author's calculations

Note: symbols * and ${ }^{* *}$ denote statistical significance at the $1 \%$ and $5 \%$ level

The final Model 4 also includes the dummy variable as presented in (11).

$\ln G D P_{i t}=\delta_{0}+\delta_{1} \ln G D P_{i t-1}+\delta_{2} d G O V_{i t}+$

$+\delta_{3} d B U S I N E S S_{i t}+\delta_{4} d E D U_{i t}+$

$+\delta_{4} d E D U_{i t}+\delta_{5} d I N V_{i t}+\delta_{6} d H R S T_{i t}+$

$+\delta_{7} d O P E N_{i t}+d u m m y i t+\varepsilon_{i t}$

The results concerning the effect of R\&D expenditure on economic growth indicate that R\&D expenditure GERD affects economic growth positively (although the effect is statistically significantly only at $10 \%$ level). This is consistent with the theoretical assumption because the positive impact of R\&D expenditure on GDP growth could be expected, especially, in medium or long term. More detailed results can be found after substituting GERD with its main components - BUSINESS, GOV and EDU R\&D expenditure. Model 3 shows that the estimated coefficient of GOV expenditure is positive and statistically significant. This finding confirms that an increase of government R\&D expenditure contributes to economic growth. It is necessary to note that government R\&D expenditure seems to be the main driver for economic growth with stronger effect next growth variables (country openness, human capital approximated by HRST or business 
R\&D expenditure). GOV expenditure can be applied for basic and applied research in accordance with preferences of R\&D strategy and founder requirements. The R\&D strategy can be planned through basic research and its effectiveness can be checked and realized by applied research. Hereby, the impact of GOV expenditure on GDP growth could be explained.

Likewise, business R\&D expenditure reports to have an influence on economic growth, as coefficients are statistically significant during the reported period. Business R\&D mostly focuses on applied research which works towards finding a specific application and goals to develop innovative technology. In this way, business sector can contribute to a better economic performance in a long term. R\&D expenditure of the business sector fell in 2008 and 2009 (and also in the following years, see OECD (2012)). As Cincera et al. (2012) noted businesses usually decrease the amount they spend on R\&D during economic crisis as a cost-reduction strategy, in times of economic pressure and tight credit constraints. A similar development was also reported in some countries in the sample of this research. For instance, the Czech Republic, Slovenia and Poland increased public R\&D expenditure with the aim to stimulate economic growth and again encourage private R\&D investment. These circumstances could explain the significant effect of business R\&D on economic growth.

Higher education is composed of universities, colleges of technology and other institutions providing formal tertiary education programmes, as well as research institutes, centres, or experimental stations. EDU R\&D expenditure affects economic performance positively, but its impact is not statistically significant. It should be noted that the value of $E D U$ R\&D expenditure is very divergent in the selected countries, as it varies from $0.02 \%$ of GDP in Bulgaria to $0.52 \%$ of GDP in the Czech Republic. Moreover, most CEE countries belong to the group of moderate or modest innovators with an insufficiently developed system of $R \& D$ in higher education. Another reason can be seen in a fact that basic research provided by universities and other scientific subjects as it lays the foundation for applied research. Thus, in line with its indirect approach, a direct connection with economic growth is not noticeable. Our results are consistent with Moutinho's et al. (2015) report as education (university) R\&D expenditure does not have any statistically significant impact on economic growth.

Surprisingly, effect of investment on GDP growth was found positive but not confirmed at standard statistical level, although it is the fundamental determinant of economic growth identified by both neoclassical and endogenous growth models, as well as in a study done by Szarowská (2017) for 20 selected EU countries. The reason may be found in the investment mix in the country sample. The composition of investment is a relevant problem in the CEE countries. As current investments significantly exceed capital investment, the influence of total investment on economic growth is negligible. Moreover, already Kneller et al. (1999) divided expenditure and investment into productive and unproductive. It means that not all investment are deemed to be growth-friendly. For this reason, it is crucial to directing investment to growth-enhancing areas, e.g. infrastructure and communication, energy, R\&D, education and health care (which both are associated with improved quality and quantity of human capital and labour force).

On the contrary, the results confirm the positive impact of HRST, a higher share of the active population having successfully completed an education at the tertiary level or being employed in science and technology. This finding is in line with the assumption that qualified human capital has a positive effect on economic growth and with conclusions of Bilbao-Osorio and Rodriguez-Pose (2004), who indicated the importance of a higher educated labour force too. Likewise Becker (2015) supported conclusions about the importance of high-skilled human capital.

Country openness has a positive effect on economic growth as was expected. Openness is an important and strong determinant of economic performance. Theoretical reasons for a positive link between openness and economic growth are based on the transfer of technology and flow of knowledge, as well as on the increased competition, which contribute to the reasonable improvement. Our results are in line with conclusions of Dritsakis and Stamatiou (2016), who researched relationship between country openness and economic growth using data for the 13 newest EU members during the period of 1990-2013, and established a longrun relationship with a short-run adjustment 
to the deviation from the equilibrium for both directions of dependency. Also Pilinkiene (2016) detected that the high-degree trade openness provides the conditions relevant to economic growth in CEE countries.

A crisis (approximated by the dummy variable) has a negative and statistically significant influence on economic growth, and this conclusion is also in line with findings of Sokolov-Mladenovic et al. (2016).

In terms of earlier published studies, Cincera et al. (2005) reached also similar results in their study. Our results are consistent e.g. with Freimane and Bālina (2016) who reported statistically significant impact of $R \& D$ expenditures on economic growth in the EU countries based on panel data regressions in the period of 2000-2013 too. The significance for the R\&D coefficient remains robust in different sub-periods, but the level of significance decreases as a sub-sample of new EU countries was considered.

Conversely, obtained results are not in line with the findings of Silaghi et al. (2014), who estimated the role of private and public R\&D in the CEE countries and found public R\&D statistically insignificant. As they provided their empirical evidence over the period 1998-2008, this limited pre-crisis time span could be a reason for explaining the deviation in the conclusions. Anyway, variety of findings in empirical studies is generated because of differences used in econometric models, country samples, observation periods and considered variables.

Overall, the model performance is satisfying. The goodness of fit is high; the adjusted coefficient of determination $\left(R^{2}\right)$ is very high. The probability of $F$ statistic is 0.00 , which indicates that the model as a whole is statistically significant. The Durbin-Watson test is used to detect the independence of residuals from the regression analysis. Its value indicates the absence of autocorrelation in the residuals and confirms the quality of the model.

Finally, it should be noted that the exact form of the relationship between R\&D and economic growth differs from country to country. Therefore, country-specific factors are crucial in modelling the R\&D and growth co-movements, Moreover, using differing conceptual and methodological approaches, studies can focus on a number of explanatory parameters and offer various explanations for economic growth.

\section{Conclusions}

The aim of the article was to quantify the effect of R\&D expenditure on economic growth in the period 1995-2016. The research applies Dumitrescu Hurlin (DH) causality and a dynamic panel regression methodology, based on adapted Solow's growth model. The presented empirical evidence is performed on unbalanced annual panel data of eight selected CEE countries and the study adds new empirical evidence to the literature.

This research confirms that there is a trend to combine direct public and indirect public funding instruments. Governments offer direct support through a variety of grants, subsidies, loans or equity funding. Because of limited financial resources, indirect support has become more important in recent years. It has been found that cash grants and tax deduction are the tools most often used for support and funding of R\&D in the selected CEE countries. As availability of more types of incentives is very important factor affecting the level of expenditure on R\&D, countries with moderate or modest R\&D expenditure, e.g. in the country sample, should offer more tax and fiscal arrangements supporting R\&D expenditure and subsequently economic growth.

The direct empirical evidence quantified and tested whether R\&D expenditure affects economic performance. $R \& D$ expenditure was investigated not only as a whole GERD but also as its components: business R\&D and public $R \& D$, represented by government and higher education R\&D expenditure. An important finding resulting from this research is that the dynamic panel analysis conclusively confirms a positive and statistically significant impact of R\&D expenditure on economic growth. Government R\&D expenditure seems to be the key driver for economic performance, followed by next growth variables (business $R \& D$, human capital approximated by $H R S T$ and country openness), so policymakers should focus their attention on this kind of R\&D support and funding. Support of business R\&D expenditure is important especially for its focus on applied research which can positively stimulate economic growth. As businesses usually react with sensitivity to external economic conditions and decrease R\&D expenditure during economic depression and crisis, it is important to increase cooperation with the public sector and encourage and stimulate their R\&D 
activities by direct and indirect funding. Based on the obtained data, it can be concluded that a higher share of the active population having successfully completed an education at the tertiary level or being employed in science and technology (HRST) influences economic growth positively. This finding supports assumptions about the increasing importance of qualified human capital or labour force, generally.

Surprisingly, investment and higher education R\&D expenditure were found to have a positive but statistically insignificant impact. This is the main difference between the conclusions of the empirical evidence and most studies. Special care of policymakers should be given to investment mix. It is decisive to direct investment to growth-enhancing areas, e.g. infrastructure and communication, R\&D, education and health care and to improve the ratio between current and capital investment. Attention should focus also on higher education R\&D support, as these education subjects can be core centres of research and can support extension of R\&D into specific fields and help the economy to become knowledge-based. Future development must be concentrate on cooperation of universities, colleges of technology and other institutions, as well as research institutes and centres with business sector especially in the area of applied research.

The crisis (approximated by a dummy variable) reports a negative and statistically significant influence on economic growth, as Sokolov-Mladenovic et al. (2016) also found. Next control variable, country openness, has a confirmed positive effect on economic growth as was expected. Openness is an important determinant of economic performance. Theoretical reasons for a positive link between openness and economic growth are based on transfer of technology, flow of knowledge, and increasing of competition, all of which contribute to the comparative advantage.

Although the research adds new empirical evidence to the literature, it should be remembered that country specifics are crucial in modelling R\&D-growth effects and strongly depend especially on their size and territory specification and socio-economic maturity.

This article was supported by the Ministry of Education, Youth and Sports Czech Republic within the Institutional Support for Long-term Development of a Research Organization in 2018.

\section{References}

Afonso, O. (2016). R\&D intensity, economic growth and firm-size growth: theory and practice. Applied Economics, 48(32), 2973-2993. https://dx.doi.org/10.1080/00036846.2015.1133896.

Arellano, M., \& Bond, S. (1991). Some tests of specification for panel data. The Review of Economic Studies, 58(2), 277-297. https://dx.doi.org/10.2307/2297968.

Baran, K. (2013). The Determinants of Economic Growth in Hungary, Poland, Slovakia and the Czech Republic during the Years 1995-2010. Equilibrium, Quarterly Journal of Economics and Economic Policy, 8(3), 7-26.

Barro, R. J., \& Sala-i-Martin, X. (1995). Economic growth. New York: McGraw-Hill.

Becker, B. (2015). Public R\&D policies and private R\&D investment: a survey of the empirical evidence. Journal of Economic Surveys, 29(5), 917-942. https://dx.doi. org/10.1111/joes.12074.

Berliant, M., \& Fujita, M. (2011). The Dynamics of knowledge diversity and economic growth. Southern Economic Journal, 77(4), 856-884. https://dx.doi.org/10.4284/00384038-77.4.856.

Bilas, V., Bosnjak, M., \& Cizmic, T. (2016). Relationship between Research and Development and Economic Growth in the EU Countries. In 13th International Scientific Conference on Economic and Social Development (pp. 223-230). Varazdin: Varazdin Development \& Entrepreneurship Agency.

Bilbao-Osorio, B., \& Rodriguez-Pose, A. (2004). From R\&D to innovation and economic growth in the EU. Growth and Change, 35(4), 434-455. https://dx.doi.org/10.1111/j.14682257.2004.00256.x.

Breitung, J. (2000). The local power of some unit root tests for panel data. In B. H. Baltagi (Ed.), Advances in Econometrics, Volume 15: Nonstationary Panels, Panel Cointegration, and Dynamic Panels (pp. 161-178). Amsterdam: JAY Press.

Cincera, M., Cozzab, C., Tübkec, A., \& Voigt, P. (2012). Doing R\&D or not (in a crisis), that is the question. European Planning Studies, 20(9), 1525-1547. https://dx.doi.org/10.1080/09 654313.2012.709064.

David, P. A., Hall, B. H., \& Toole, A. A. (2000). Is public R\&D a complement or substitute for private R\&D? A review of the econometric evidence. Research Policy, 29(4-5), 497-529. https://doi.org/10.1016/S0048-7333(99)00087-6. 
Dougherty, C. (2007). Introduction to Econometrics. Oxford: Oxford University Press.

Dritsakis, N., \& Stamatiou, P. (2016). Trade Openness and Economic Growth: A Panel Cointegration and Causality Analysis for the Newest EU Countries. Romanian Journal of Economic Forecasting, 19(59), 45-60.

Dumitrescu, E. I., \& Hurlin, C. (2012). Testing for Granger non-causality in heterogeneous panels. Economic Modelling, 29(4), 1450-1460. https://doi.org/10.1016/j. econmod.2012.02.014.

Ernst \& Young. (2015). Worldwide R\&D incentives reference guide 2014-15. London: EYGM Limited.

European Commission. (2014). Taking stock of the Europe 2020 strategy for smart, sustainable and inclusive growth, COM (2014) 130 final. Brussels: European Commission.

European Commission. (2013). Research and innovation performance in EU member states and associated countries. Luxembourg: Publications Office of the European Union.

Freimane, R., \& Bāliņa, S. (2016). Research and Development Expenditures and Economic Growth in the EU: A Panel Data Analysis. Economics and Business, 29(1), 5-11. https:// doi.org/10.1515/eb-2016-0016.

Garland, G. H., \&Allen, D. B. (1995). Returns on public and private R\&D. In 3rd International Meeting of the Decision-Sciences-Institute on Competing in the Global Marketplace (pp.165167). Atlanta: Decision Sciences Institute.

Gemmell, N., Kneller, R., \& Sanz, I. (2015). The growth effects of tax rates in the OECD. Canadian Journal of Economics, 47(4), 12171255. https://doi.org/10.1111/caje.12105.

Grossman, G., \& Helpman, E. (1991). Trade, knowledge spillovers, and growth. European Economic Review, 35(2-3), 517-526. https://doi.org/10.1016/0014-2921(91)90153-A.

Guellec, D., \& van Pottelsberghe, B. (2003). The impact of public R\&D expenditure on business R\&D. Economics of Innovation and New Technology, 12(3), 225-243. https://dx.doi. org/10.1080/10438590290004555.

Gumus, E., \& Celikay, F. (2015). R\&D Expenditure and Economic Growth: New Empirical Evidence. The Journal of Applied Economic Research, 9(3), 205-217. https:// dx.doi.org/10.1177/0973801015579753.

Hall, B., \& Van Reenen, J. (2000). How effective are fiscal incentives for R\&D? A review of the evidence. Research Policy, 29(4-5),
449-469. https://dx.doi.org/10.1016/S00487333(99)00085-2.

Hud, M., \& Hussinger, K. (2015). The impact of R\&D subsidies during the crisis. Research Policy, 44(10), 1844-1855. https://dx.doi.org/10.1016/j.respol.2015.06.003.

Huňady, J., \& Orviská, M. (2014). The Impact of Research and Development Expenditures on Innovation Performance and Economic Growth of the Country - the Empirical Evidence. CBU International Conference Proceedings, 2, 119-125. https://dx.doi.org/10.12955/cbup.v2.454.

Chvojka, P., \& Zeman, K. (2000). Tendencies of the Central and East European countries development. Politická ekonomie, 48(6), 799-822.

Im, K. S., Pesaran, M. H., \& Shin, Y. (2003). Testing for unit roots in heterogeneous panels. Journal of Econometrics, 115(1), 53-74. https://doi.org/10.1016/S0304-4076(03)00092-7.

Inekwe, J. N. (2015). The Contribution of R\&D Expenditure to Economic Growth in Developing Economies. Social Indicators Research, 124(3), 727-745. https://dx.doi. org/10.1007/s11205-014-0807-3.

Jones, C. I. (1995). R\&D-based models of economic growth. Journal of Political Economy, 103(4), 759-784. https://dx.doi. org/10.1086/262002.

Köhler, C., Laredo, P., \& Rammer, C. (2012). The impact and effectiveness of fiscal incentives for R\&D [Nesta Working Paper 12/01]. London: NESTA. Retrieved December 12,2015 , from www.nesta.org.uk/sites/default/ files/the_impact_and_effectiveness_of_fiscal_ incentives.pdf.

Kneller, R., Bleaney, M. F., \& Gemmell, N. (1999). Fiscal policy and growth: evidence from OECD countries. Journal of Public Economics, 74(2), 171-190. https://doi.org/10.1016/S00472727(99)00022-5.

Kravtsova, V., \& Radosevic, S. (2012). Are systems of innovation in Eastern Europe efficient? Economic Systems, 36(1), 109-126. https://doi.org/10.1016/j.ecosys.2011.04.005.

Levin, A., Lin, C. F., \& Chu, C.-S. J. (2002). Unit root tests in panel data: Asymptotic and finite-sample properties. Journal of Econometrics, 108(1), 1-24. https://doi. org/10.1016/S0304-4076(01)00098-7.

Minniti, A., \& Venturini, F. (2017). The longrun growth effects of R\&D policy. Research Policy, 46(1), 316-326. https://doi.org/10.1016/j. respol.2016.11.006. 
Moutinho, R., Au-Yong-Oliveira, M., Coelho, A., \& Manso, J. P. (2015). Beyond the "Innovation's Black-Box": Translating R\&D outlays into employment and economic growth. Socio-Economic Planning Sciences, 50, 45-58. https://doi.org/10.1016/j.seps.2015.04.001.

OECD. (2012). OECD science, technology and industry outlook 2012. Paris: OECD Publications Service. https://dx.doi. org/10.1787/19991428.

OECD. (2015). OECD science, technology and industry scoreboard 2015: innovation for growth and society. Paris: OECD Publishing. https://dx.doi.org/10.1787/20725345.

OECD. (2017). OECD Science, Technology and Industry Scoreboard 2017: The digital transformation. Paris: OECD Publishing. https:// dx.doi.org/10.1787/9789264268821-en.

Perez-Sebastian, F. (2007). Public support to innovation and imitation in a non-scale growth model. Journal of Economic Dynamics \& Control, 31(12), 3791-3821. https://dx.doi. org/10.1016/j.jedc.2006.12.011.

Petrakos, G., Arvanitidis, P. (2008). Determinants of economic growth. Economic alternatives, 1, 11-30.

Pilinkiene, V. (2016). Trade Openness, Economic Growth and Competitiveness. The Case of the Central and Eastern European Countries. Engineering Economics, 27(2), 185-194. https://dx.doi.org/10.5755/j01.ee.27.2.14013.

Romer, P. M. (1986). Increasing Returns and Long-Run Growth. Journal of Political Economy, 94(5), 1002-1037. https://doi. org/10.1086/261420.

Romer,P.M.(1990). Endogenous Technological Change. Journal of Political Economy, 98(5), 71-102. https://doi.org/10.1086/261725.

Silaghi, M. P., \& Alexa, D. (2015). Sources of growth: Evidence from ten central and eastern European countries during 1993-2008. Panoeconomicus, 62(5), 643-661. https://doi. org/10.2298/PAN1505643P.

Silaghi, M. P., Alexa, D., Jude, C., \& Litan, C. (2014). Do business and public sector research and development expenditures contribute to economic growth in Central and Eastern European Countries? A dynamic panel estimation. Economic Modelling, 36, 108-119. https://dx.doi.org/10.1016/j. econmod.2013.08.035.

Simionescu, M., Lazányi, K., Sopková, G., Dobeš, K., \& Balcerzak, A. P. (2017). Determinants of Economic Growth in V4 Countries and Romania. Journal of Competitiveness, 9(1), 103-116. https://doi. org/10.7441/joc.2017.01.07.

Sokolov-Mladenovic, S., Cvetanovic, S., \& Mladenovic, I. (2016). R\&D expenditure and economic growth: EU28 evidence for the period 2002-2012. Economic Research-Ekonomska Istrazivanja, 29(1), 1005-1020. https://doi.org/ 10.1080/1331677X.2016.1211948.

Solow, R. (1956). A Contribution to the Theory of Economic Growth. The Quarterly Journal of Economics, 70(1), 65-94. https://dx.doi.org/10.2307/1884513.

Sylwester, K. (2001). R\&D and economic growth. Knowledge, Technology \& Policy, 13(4), 71-84. https://dx.doi.org/10.1007/BF02693991.

Szarowská, I. (2017). Does public R\&D expenditure matter for economic growth? GMM approach. Journal of International Studies, 10(2), 90-103. https://dx.doi. org/10.14254/2071-8330.2017/10-2/6.

Szarowská, I. (2016). Impact of Public R\&D Expenditure on Economic Growth in Selected EU Countries. In 9th International Scientific Conference „Business and Management 2016“. Vilnius: VGTU Press. https://dx.doi. org/10.3846/bm.2016.1

Verbeek, M. (2012). A guide to modern econometrics (4th ed.). New York: John Wiley \& Sons.

Ing. Irena Szarowská, Ph.D.

Silesian University in Opava School of Business Administration Department of Finance and Accounting Czech Republic szarowska@opf.slu.cz 


\section{Abstract}

\section{IMPORTANCE OF R\&D EXPENDITURE FOR ECONOMIC GROWTH IN SELECTED CEE COUNTRIES}

\section{Irena Szarowská}

The goal of the article is to quantify the effect of $R \& D$ expenditure on economic growth in selected Central and Eastern European countries. From a methodological perspective, the research is based on Dumitrescu and Hurlin causality and the dynamic panel regression methodology, based on adapted growth model. The empirical evidence is performed on unbalanced annual panel data of eight selected countries (Bulgaria, Czech Republic, Hungary, Latvia, Poland, Romania, Slovak Republic and Slovenia), during the period 1995-2016. The research confirms that there is a trend to combine direct and indirect public funding instruments. Because of limited financial resources, indirect support has become more important in recent years. Cash grants and tax deduction are the tools most often used for support and funding of R\&D in the selected CEE countries.

A dynamic panel analysis with fixed effects confirms a positive and statistically significant impact of $R \& D$ expenditure on economic growth. Government $R \& D$ expenditure is reported to be a key driver for economic performance followed by business R\&D expenditure, a higher share of persons with tertiary education and/or employed in science and technology and country openness. On the contrary, investment and higher education R\&D expenditure were found to have a positive but statistically insignificant impact. Hence, special care of policymakers should be given to investment mix. It is decisive to direct and support investment to growth-enhancing areas (e.g. infrastructure and communication, $R \& D$, education and health care) and to improve the ratio between current and capital investment. Attention should also focus on higher education R\&D support, and future development must be concentrate on its cooperation with business sector especially in the area of applied research. Finally, a crisis is reported to have a negative and statistically significant impact on economic growth.

Key Words: Research and development, economic growth, public expenditure, Dumitrescu and Hurlin causality, dynamic panel regression.

JEL Classification: O38, O47, H50, C33.

DOI: 10.15240/tul/001/2018-4-008 